ORIGINAL ARTICLE

\title{
Expression of granulocyte colony stimulating factor receptor in human colorectal cancer
}

\author{
X Yang, F Liu, Z Xu, C Chen, X Wu, G Li, J Li
}

Postgrad Med J 2005;81:333-337. doi: 10.1136/pgmj.2004.024646

\begin{abstract}
See end of article for authors' affiliations

Correspondence to: Mr X Yang, Department of General Surgery, Jinling Hospital, 305 Zhongshangdong Road, Nanjing, 210002, China; yangxd96@hotmail.com
\end{abstract}

Submitted 26 May 2004 Accepted 1 August 2004

\begin{abstract}
Aims: To discover if human colorectal cancer expresses granulocyte colony stimulating factor receptor (GCSFR) and if granulocyte colony stimulating factor (G-CSF) plays an important part in the development and progression of human colorectal cancer.

Methods: Forty two specimens of colorectal cancer and normal colorectal mucosa were investigated, taken from the colon or rectum in group of colorectal cancer patients. Immunohistochemistry and reverse transcription polymerase chain reaction (RT-PCR) technique were used to show G-CSFR expression. The relation between expression of G-CSFR and clinical or pathological factors was analysed.

Results: Immucohistochemical analyses showed that G-CSFR was expressed in the human colorectal cancer $(25$ of $42,59.52 \%$ ) and seemed to be up-regulated compared with the normal mucosa ( 14 of 42 , $33.33 \%, p<0.001$ ). In pronounced contrast with mostly strongly positive tumours, corresponding normal colorectal mucosa was negative or weakly positive. A significant correlation was found between G-CSFR expression and tumour stage $(p=0.001)$, tumour differentiation $(p<0.001)$, but there was no significant relation between the expression of G-CSFR and the age, sex, and tumour size $(p=0.346, p=0.686$, $p=0.459)$. In RT-PCR, 21 of all 42 tumours had G-CSFR mRNA expression, while only 11 of 42 normal colorectal mucosa had such expression.

Conclusions: These data show that G-CSFR is commonly expressed in human colorectal cancers, thus supporting a possible role for G-CSF in colorectal cancer physiology.
\end{abstract}

$\mathrm{R}$ ecombinant human granulocyte colony stimulating factor (rhG-CSF) is a peptide hormone known to be responsible for the in vitro and in vivo proliferation of bone narrow progenitor cells into mature differentiated cells. It is clinically used to overcome neutropenic periods during chemotherapy. ${ }^{2}$ In vitro studies using cell lines as a model system have recently suggested that G-CSF can promote cancer growth. G-CSFR was first studied on haematopoietic cells, such as myeloid progenitor cell, ${ }^{3}$ mature neutrophils, ${ }^{5}$ platelets, monocytes, and some T and B lymphoid cell lines. ${ }^{67}$ Several non-haematopoietic cells also express G-CSFR including endothelial cell, ${ }^{8}$ placenta, ${ }^{10-12}$ trophoblastic cell. ${ }^{13}$ The role of G-CSF in malignant tumour cells as well as their significance in cancer development is not clear. The incubation of different cancer cell lines and primary tumours with recombinant human (rh) G-CSF induced diverse reactions. While the leukaemia cell line U-937 suffered growth inhibition, ${ }^{14}$ the murine pro-B cell line BAF-3 reacts with a $60 \%$ raised DNA synthesis. ${ }^{15}{ }^{16}$ Cell proliferation was also seen for the murine cell line NFS- $60,{ }^{17}$ the osteosarcoma cell line MG63, ${ }^{18}$ and bladder cancer cells. ${ }^{19}$ Colorectal cancer (CRC) is a common malignancy. Whether it expressed G-CSFR has not been reported. The aim of the work is to investigate whether CRC cells as well as corresponding normal mucosa express GCSF protein and mRNA using immunohistochemistry and RT-PCR.

\section{METHODS}

\section{Patients and tissue samples}

The case list of our study includes CRC specimens from 42 different patients with histologically confirmed CRC admitted to the department of general surgery of Jinling Hospital in Nanjing, China from September 2003 to December 2003. The age and sex of patients, tumour size, tumour differentiation, and tumour stage were recorded in all cases (table 1). Tumour tissue and normal mucosa tissue (taken $10 \mathrm{~cm}$ apart from the tumour) were obtained in all cases. Histological examination was performed routinely in all of the cases. Immunohistochemical analyses were also performed in all 42 cases. Tumour histotype and grade of differentiation were defined according to the WHO criteria.

\section{Immunohistochemistry}

For formalin fixed and paraffin wax embedded tissue specimens, consecutive $4 \mu \mathrm{m}$ thick sections were cut and used for immunohistochemistry (IHC).

The sections were immunohistochemically stained by the labelled streptavidin-biotin peroxidase method (LSAB2 Kit; Dako Japan, Kyoto, Japan) with the following primary antibodies: mouse monoclonal antibodies G-CSFR (Serotec, United Kingdom, dilution 1:80). The slides were immersed for 10 minutes in $0.3 \%$ hydrogen peroxide/methanol to deplete endogenous peroxidase. Then, non-specific binding sites were blocked with $0.3 \%$ normal goat serum for 10 minutes. The primary antibody was then applied, and the sections were incubated overnight at $4^{\circ} \mathrm{C}$. After washing with phosphate buffered saline (PBS) (0.01 mol/l pH 7.4), biotinylated goat antimouse IgG was applied to the tissue sections and incubated at room temperature for 10 minutes. After washing with PBS, a streptavidin peroxidase reagent was applied and incubated at room temperature for 10 minutes. Finally, the reaction product was visualised using developing colour by incubating the slides in a solution of $0.3 \%$ hydrogen peroxide and AEC chromogen. The sections were counterstained slightly with haematoxylin. Negative controls included parallel sections treated without the primary antibody, in addition to negate an adjacent section of the same block in which the primary antibody was

Abbreviations: G-CSFR, granulocyte colony stimulating factor receptor; CRC, colorectal cancer; $I H C$, immunohistochemistry; RT-PCR, reverse transcription polymerase chain reaction 
Table 1 Summary of clinical data of 42 carcinomas and RT-PCR, immunohistochemical analyses

\begin{tabular}{|c|c|c|c|c|c|c|c|c|c|c|}
\hline \multirow[b]{3}{*}{ Case number } & \multirow[b]{3}{*}{ Age (y) } & \multirow[b]{3}{*}{ Sex } & \multirow[b]{3}{*}{ Position } & \multirow[b]{3}{*}{ Tumour size $(\mathrm{cm})$} & \multirow[b]{3}{*}{ Differentiation } & \multirow[b]{3}{*}{ Stage (I-IV) } & \multicolumn{4}{|c|}{ G-CSFR detection } \\
\hline & & & & & & & \multicolumn{2}{|c|}{ RT-PCR } & \multicolumn{2}{|c|}{$\mathrm{IHC}(0-3)$} \\
\hline & & & & & & & $\mathbf{T}$ & $\mathbf{N}$ & $T$ & $\mathbf{N}$ \\
\hline 1 & 63 & $M$ & $\mathrm{R}$ & $1 \times 2$ & poorly & $\|$ & + & + & 3 & 2 \\
\hline 2 & 70 & $M$ & $\mathrm{R}$ & $4 \times 5$ & poorly & III & + & - & 3 & 0 \\
\hline 3 & 75 & $\mathrm{~F}$ & $\mathrm{R}$ & $2 \times 3$ & moderately & IV & + & - & 3 & 1 \\
\hline 4 & 70 & $M$ & $\mathrm{~S}$ & $3 \times 3$ & moderately & ॥ & - & - & 1 & 0 \\
\hline 5 & 58 & $\mathrm{~F}$ & $\mathrm{R}$ & $3 \times 4$ & moderately & I & - & - & 0 & 0 \\
\hline 6 & 65 & $M$ & D & $3 \times 2$ & moderately & $\|$ & - & - & 0 & 0 \\
\hline 7 & 61 & $\mathrm{~F}$ & $\mathrm{R}$ & $4 \times 3$ & well & III & + & + & 2 & 2 \\
\hline 8 & 37 & $\mathrm{~F}$ & $\mathrm{R}$ & $2 \times 3$ & well & 1 & - & - & 0 & 0 \\
\hline 9 & 90 & $M$ & $\mathrm{R}$ & $2 \times 2$ & poorly & IV & + & + & 3 & 2 \\
\hline 10 & 39 & $M$ & $\mathrm{R}$ & $4 \times 5$ & well & II & - & - & 0 & 0 \\
\hline 11 & 55 & $M$ & D & $3 \times 4$ & moderately & II & + & + & 2 & 2 \\
\hline 12 & 73 & $M$ & $\mathrm{R}$ & $3 \times 4$ & moderately & 1 & - & - & 0 & 0 \\
\hline 13 & 46 & $\mathrm{~F}$ & $\mathrm{R}$ & $3 \times 3$ & poorly & 1 & + & - & 3 & 1 \\
\hline 14 & 60 & $\mathrm{~F}$ & A & $4 \times 5$ & poorly & III & + & + & 3 & 3 \\
\hline 15 & 56 & $M$ & $S$ & $3 \times 5$ & moderately & III & - & - & 0 & 0 \\
\hline 16 & 47 & $\mathrm{~F}$ & $\mathrm{R}$ & $2 \times 3$ & poorly & I & + & - & 2 & 0 \\
\hline 17 & 77 & $M$ & $\mathrm{R}$ & $3 \times 4$ & moderately & II & + & + & 2 & 1 \\
\hline 18 & 55 & $M$ & $\mathrm{~T}$ & $2 \times 3$ & moderately & 1 & - & - & 1 & 0 \\
\hline 19 & 46 & $M$ & $\mathrm{R}$ & $4 \times 4$ & well & II & - & - & 0 & 0 \\
\hline 20 & 65 & $\mathrm{~F}$ & $\mathrm{R}$ & $5 \times 5$ & well & ॥ & - & - & 0 & 0 \\
\hline 21 & 73 & $\mathrm{~F}$ & A & $3 \times 5$ & moderately & II & - & - & 0 & 0 \\
\hline 22 & 65 & $\mathrm{~F}$ & $\mathrm{R}$ & $2 \times 3$ & moderately & III & + & - & 2 & 0 \\
\hline 23 & 48 & $M$ & $\mathrm{R}$ & $1 \times 3$ & well & I & - & - & 0 & 0 \\
\hline 24 & 80 & $M$ & $\mathrm{R}$ & $5 \times 6$ & moderately & II & - & - & 1 & 0 \\
\hline 25 & 46 & $\mathrm{~F}$ & $S$ & $1 \times 1$ & moderately & I & - & - & 1 & 0 \\
\hline 26 & 33 & $M$ & $\mathrm{R}$ & $2 \times 3$ & poorly & II & + & + & 3 & 2 \\
\hline 27 & 44 & $M$ & $\mathrm{R}$ & $2 \times 2$ & moderately & II & + & - & 1 & 0 \\
\hline 28 & 49 & $\mathrm{~F}$ & A & $4 \times 4$ & well & I & - & - & 0 & 0 \\
\hline 29 & 67 & $\mathrm{~F}$ & $\mathrm{R}$ & $5 \times 6$ & moderately & II & + & - & 2 & 0 \\
\hline 30 & 76 & $M$ & $\mathrm{R}$ & $3 \times 5$ & moderately & III & + & + & 3 & 1 \\
\hline 31 & 71 & $M$ & $\mathrm{R}$ & $1 \times 2$ & well & 1 & - & - & 0 & 0 \\
\hline 32 & 63 & $M$ & $A$ & $5 \times 6$ & poorly & IV & + & + & 3 & 2 \\
\hline 33 & 74 & $M$ & $\mathrm{R}$ & $4 \times 5$ & moderately & II & + & - & 2 & 1 \\
\hline 34 & 80 & $\mathrm{~F}$ & D & $1 \times 2$ & moderately & 1 & + & - & 1 & 0 \\
\hline 35 & 72 & $M$ & $\mathrm{R}$ & $2 \times 3$ & well & $\|$ & - & - & 0 & 0 \\
\hline 36 & 43 & $M$ & A & $2 \times 2$ & well & $\|$ & - & - & 0 & 0 \\
\hline 37 & 50 & $\mathrm{~F}$ & $\mathrm{R}$ & $4 \times 5$ & moderately & III & + & - & 2 & 0 \\
\hline 38 & 60 & $M$ & D & $2 \times 3$ & moderately & ॥ & - & - & 0 & 0 \\
\hline 39 & 64 & $M$ & $\mathrm{R}$ & $3 \times 3$ & well & I & - & - & 0 & 0 \\
\hline 40 & 48 & $\mathrm{~F}$ & $\mathrm{R}$ & $3 \times 4$ & moderately & IV & + & + & 3 & 2 \\
\hline 41 & 50 & $\mathrm{~F}$ & $\mathrm{R}$ & $2 \times 2$ & moderately & $\|$ & - & - & 0 & 0 \\
\hline 42 & 15 & $M$ & $\mathrm{R}$ & $6 \times 7$ & poorly & III & + & + & 3 & 3 \\
\hline
\end{tabular}

replaced by PBS. The immunoreactions were graded as negative $(0)$, weakly positive (1), moderately positive (2), or strongly positive (3) according to the immunostaining

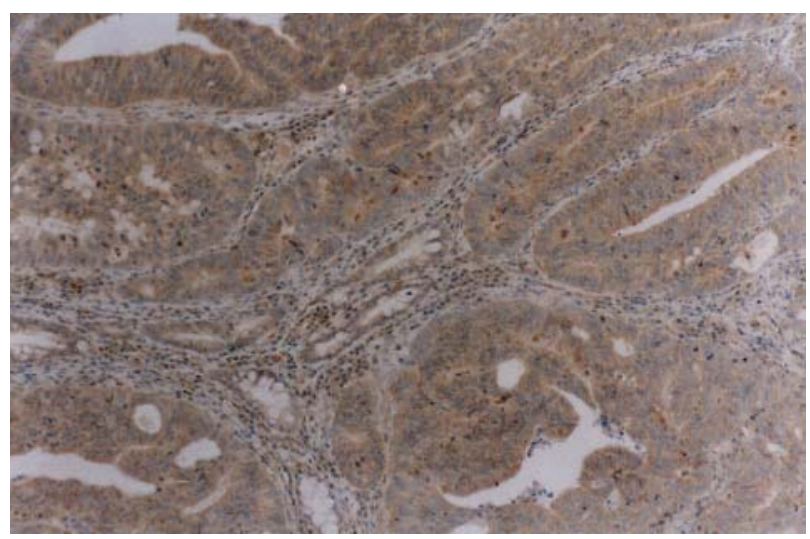

Figure 1 G-CSFR positive immunostaining of colorectal cancers $(\mathrm{SP} \times 100)$. intensity by at least two pathologists who were blinded to this study.

\section{RNA extraction}

Forty two freshly frozen colorectal cancer tissue samples and normal colorectal mucosa, $80 \mathrm{mg}$ of each, were collected and minced and total RNA was extracted with the guanidinium thiocyanate method. RNA integrity was checked by agarose gel electrophoresis and ethidium bromide staining as well as monitoring absorbance at A260/280 before each RT-PCR. RNA concentration was determined by spectrophotometric analysis at $260 \mathrm{~nm}$ and before each RT-PCR.

\section{RT-PCR}

The key points of the RT-PCR method are summarised as follows. One step RNA PCR Kit was used for PCR amplification in $50 \mu \mathrm{l}$ volume containing $5 \mathrm{mmol} / \mathrm{l} \mathrm{MgCl}_{2}, 0.8 \mathrm{U} / \mu \mathrm{l}$ RNase inhibitor, 0.1 U/ $\mu \mathrm{l}$ AMV reverse transcriptase XL, 0.4 $\mu \mathrm{mol} / \mathrm{l}$ sense and antisense primer, $0.2 \mathrm{mmol} / \mathrm{l}$ of dNTP, $0.1 \mathrm{U}$ of AMV-opitimised Taq polymerase, and $5 \mu \mathrm{l} 10 \times$ reaction buffer (TaKaRa Biotechnology, Dalian, China). RNA ( $1 \mathrm{mg}$ ) was converted into cDNA by incubating 30 minutes at $50^{\circ}$. The mixture was incubated for two minutes at $94^{\circ}$ to inactivate reverse transcriptase XL. PCR amplification was 


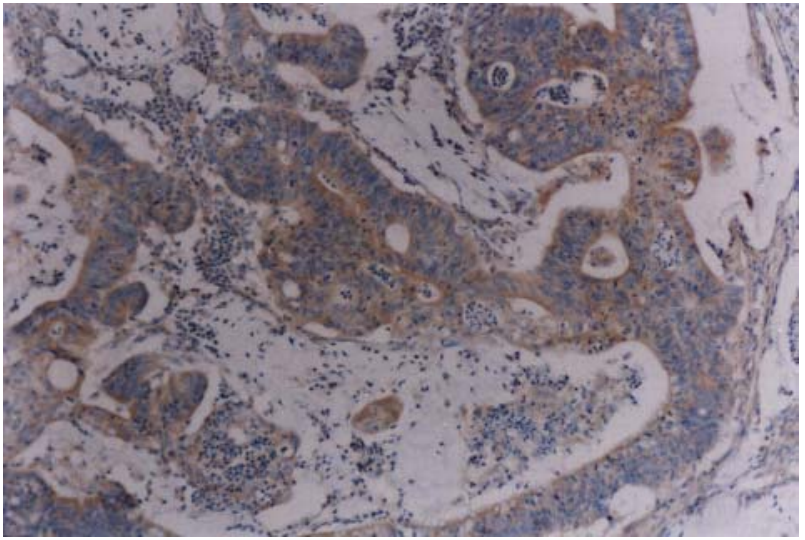

Figure 2 G-CSFR positive immunostaining of colorectal cancers $(\mathrm{SP} \times 100)$.

performed for 30 cycles consisting of 30 seconds at $94^{\circ}$, one minute at $62^{\circ}$, and one minute at $72^{\circ}$ plus elongation seven minutes at $72^{\circ}$. After amplification $20 \mu \mathrm{l}$ of the PCR reaction mix were electrophoresed in a $2 \%(\mathrm{wt} / \mathrm{vol})$ agarose gel. The PCR-amplicon had a size of 276 bp (figs 2 and 3). For the PCR reaction, the following primers were used: $5^{\prime}$ CCTGGAGCTGAGAACTACCG $-3^{\prime}$ (sense) and 5'TCCCGGCTGAGTTATAGG -3' (antisense). PCR primers were designed according to the published sequence of G-CSF receptor cDNA. The quality of cDNA for amplification reaction was proved by $\beta$ actin amplification by the same PCR protocol. As a result a $599 \mathrm{bp}$-amplicon was obtained. The $\beta$ actin primers were designed as follows: sense primer: 5'-CATTTCCGGTGCACGATGGAG-3' and the antisense primer: 5'-GCCATCCTAGCGTCTGGACCTG-3'.

\section{Statistical analysis}

The Mann-Whitney U and Kruskal-Wallis tests were used to examine the correlation between various clinical or pathological parameters and the expression of G-CSFR of tumours. Differences in G-CSFR expression between tumours and normal colorectal mucosa as determined by IHC analysis were evaluated using a Wilcoxon signed ranks test. A p values less than 0.05 were considered significant. All the calculations were performed by SPSS 10.0 for Windows.

\section{RESULTS}

Table 1 summarises the patient and tumour characteristics. The 42 patients ranged in age from 15 years to 90 years

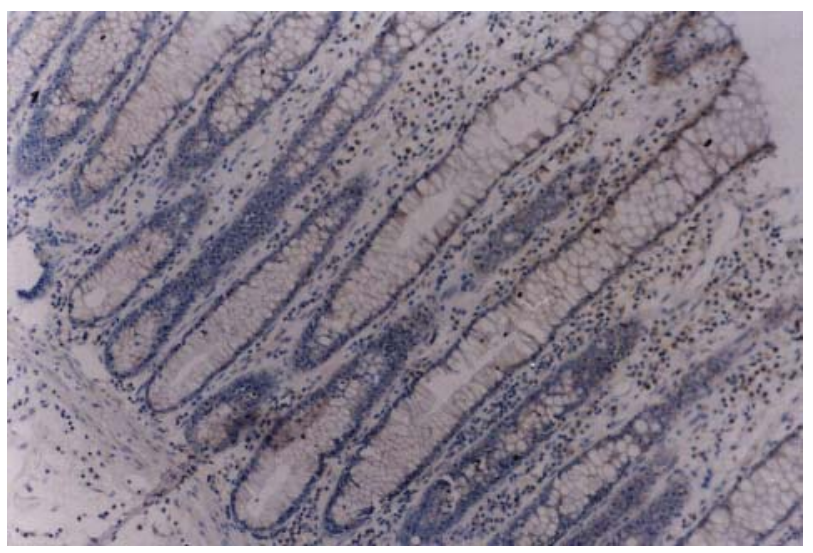

Figure 3 Negative G-CSFR immunostaining of the normal colorectal mucosa $(\mathrm{SP} \times 100)$.

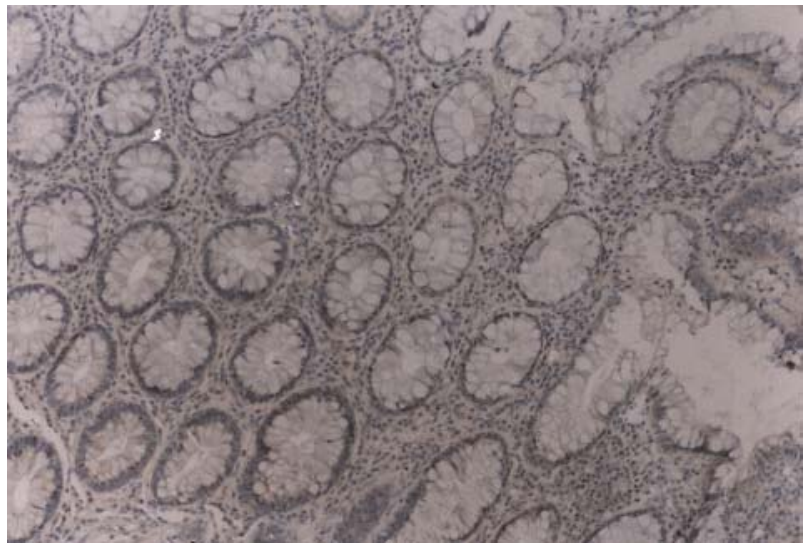

Figure 4 Negative G-CSFR immunostaining of the normal colorectal mucosa $(\mathrm{SP} \times 100)$.

(median 59). There were 25 male patients and 17 female patients. Tumours ranged from $1 \mathrm{~mm}^{2}$ to $42 \mathrm{~mm}^{2}$ in area. Most of the differentiation of tumours was moderately differentiation $(n=22)$, and the remainder were well differentiation $(n=11)$, poorly differentiation $(n=9)$. The patients included stage I (12), stage II (18), stage III (8), and stage IV (4).

\section{Immunohistochemistry}

Table 1 summarises the G-CSFR immunostaining results. A variable degree of cytoplasmic staining of tumour cells was seen in 25 of the 42 analysed tumours (59.52\%) (figs 1 and 2 ). Weak or moderate cytoplasmic staining also occurred in some stromal cells (figs 1 and 2). Seventeen of all 42 tumours were negative. Only 14 of 40 normal mucosa expressed the GCSFR protein $(33.33 \%)$. The corresponding normal colorectal mucosa was negative or weakly positive (figs 3 and 4), sharply contrasting with mostly strongly positive tumours (figs 1 and 2). A significant inverse correlation was found between G-CSFR expression and tumour stage $(p=0.001)$, tumour differentiation $(\mathrm{p}<0.001)$. There was no significant difference between G-CSFR expression and age $(p=0.346)$, $\operatorname{sex}(p=0.686)$, and tumour size $(p=0.459)$.

\section{RT-PCR}

Amplified fragments of the expected sizes (276 bp) were detected in 21 of all 42 tumour samples examined (fig 5 and table 1). In 11 cases, G-CSFR mRNA expression was also
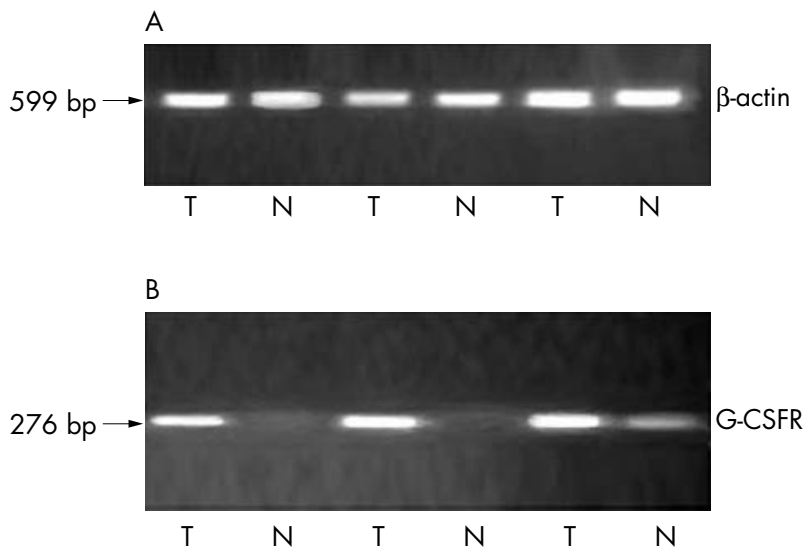

Figure 5 (A) RT-PCR of $\beta$ actin; (B) representative RT-PCR of G-CSFR expression in three colorectal cancer tissues and corresponding colorectal mucosa. 


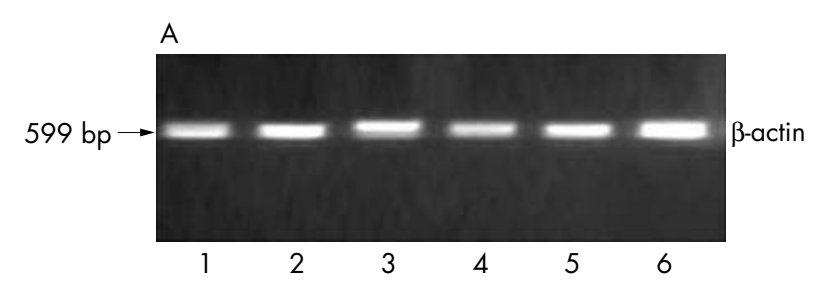

B

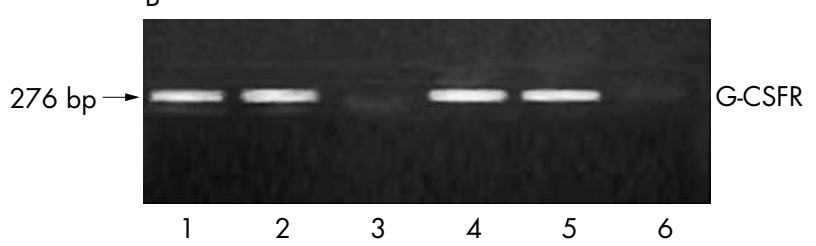

Figure 6 (A) RT-PCR of $\beta$ actin; (B) RT-PCR of G-CSFR expression in six colorectal cancer cases.

assessed in normal colorectal mucosa, and the remaining 31 cases had no G-CSFR mRNA expression (fig 6 and table 1).

\section{DISCUSSION}

The expression of cytokine receptors on malignant tumour cells $^{20} 21$ as well as the cytokine balance in the tumour microenvironment ${ }^{22}{ }^{23}$ may be relevant for cell proliferation, differentiation, or apoptosis. Receptors for G-CSF have been found on cell lines derived from human small cell carcinoma of the lung, ${ }^{24}$ in astrocytoma cell lines, ${ }^{25}$ ovarian cancer cell lines, ${ }^{26}$ and on primary bladder cancer ${ }^{27}$ and nasopharyngeal carcinoma. ${ }^{28}$ In this work, we investigated the expression of G-CSFR on CRC. Immunohistochemistry studies showed the presence of G-CSFR on 31 of 42 colorectal cancers, while only 20 of 42 corresponding normal colorectal mucosa expressed G-CSFR. These results confirm the expression of G-CSFR in CRC and show for the first time that its expression seemed to be up-regulated compared with the normal mucosa. The adjacent normal mucosa showed no or weak immunoreactivity for G-CSFR, but most carcinomas showed strong or moderate diffuse cytoplasmic staining. Thus, G-CSFR is expressed in CRC cells in vivo. This finding reinforces our understanding of the role of G-CSF in CRC.

The behaviour of colorectal tumours expressing G-CSFR may therefore be influenced by G-CSF local concentration. GCSF can be produced either by white blood cells, which frequently infiltrate colorectal tumours, ${ }^{29}$ or even by cancer cells themselves, ${ }^{30}{ }^{31}$ as has been shown for cultured bladder carcinoma $^{31}$ and astrocytoma cell lines. ${ }^{32}$ We had not looked for G-CSF production in this report. However, it is important to point out that certain conditions might be required to trigger G-CSF production in these cells. Autocrine/paracrine mechanisms have been suggested.

The downstream G-CSF signalling in non-haematopoietic cells is not well understood..$^{33}$ In contrast, it has been intensively studied in haematopoietic cells. ${ }^{34}$ Several phosphorylation cascades, ${ }^{35}$ including the ras-MAP kinase route and JAK tyrosine kinases, are activated by ligand binding to G-CSFR. Distinct regions of the G-CSF receptor ${ }^{36}$ cytoplasmic domains are required for interaction with specific molecules of each pathway. The differential expression of the five GCSFR isoforms, ${ }^{36-38}$ which differ in their cytoplasmic domains, is speculated ultimately to regulate proliferation and maturation of myeloid cells. In this study, the function of G-CSFR has not been detected. The proliferative effect of G-CSF to $\mathrm{CRC}$ in vivo and in vitro and the mechanism were also not studied. In fact, Takeshi Natori et $a l^{39}$ found that G-CSF promoted tumour growth and neovascularisation in vivo, whereas G-CSF had no effect on cell proliferation in vitro. Sara Calatayud et al ${ }^{40}$ reported diminished spontaneous apoptosis or sulindac sulphide induced apoptosis of human colon epithelial HT-29 cells in the presence of CSF. Their results suggest that G-CSF probably promotes tumour growth by stimulating neovascularisation or reducing apoptosis.

To further understand the mechanisms involved, additional studies are necessary, including analyses of benign colorectal lesions and precancerous conditions.

Recently, a significant association between G-CSFR expression in cancer cells and a poor prognosis in patients with oral and nasopharyngeal squamous cell carcinoma has been reported. To improve clinical approaches with patients suffering CRC it seems important to find out if similar associations are also present. To find correlations between GCSFR expression in colorectal cancer and clinical parameters as well as prognostic factors, further studies with higher number of cases are needed.

In summary, the results presented here show that G-CSFR is frequently expressed in CRC cells. Further research is required before deciding if our findings may have clinical implications for the use of G-CSF on CRC.

\section{Authors' affiliations}

X Yang, F Liu, Z Xu, C Chen, X Wu, G Li, J Li, Medical College, Nanjing University, Nanjing, Jingsu, China

Funding: none.

Conflicts of interest: none declared.

\section{REFERENCES}

1 Muller H, Nakchbandi W, Chatzissavvidis I, et al. Intra-arterial infusion of 5fluorouracil plus granulocyte-macrophage colony-stimulating factor (GM-CSF) and chemoembolization with melphalan in the treatment of disseminated colorectal liver metastases. Eur J Surg Oncol 2001;27:652-61.

2 Scheithaver W, Kornek GV, Raderer M, et al. Combined irinotecan and oxaliplatin plus granulocyte colony-stimulating factor in patients with advanced fluoropyrimidine/leucovorin-pretreated colorectal cancer. J Clin Oncol 1999;17:902-6.

3 Richards MK, Liu F, Iwasaki H, et al. Pivotal role of granulocyte colonystimulating factor in the development of progenitors in the common myeloid pathway. Blood 2003;102:3562-8.

4 Kaplinsky C, Trakhtenbrot L, Hardan I, et al. Tetraploid myeloid cells in donors of peripheral blood stem cells treated with rhG-CSF. Bone Marrow Transplant 2003;32:31-4

5 Chakraborty A, Hentzen ER, Seo SM, et al. Granulocyte colony-stimulating factor promotes adhesion of neutrophils. Am J Physiol Cell Physiol 2003;284:C103-10.

6 Chen SH, Li X, Huang XJ. Effect of recombinant human granulocyte colonystimulating factor on T-lymphocyte function and the mechanism of this effect. Int J Hematol 2004;79:178-84.

7 Arat M, Arslan O, Gurman G, et al. The impact of granulocyte colony stimulating factor at content of donor lymphocytes collected for cellular immunotherapy. Transfus Apheresis Sci 2004;30:9-15.

8 Campbell CL, Savarese DM, Quesenberry PJ, et al. Expression of multiple angiogenic cytokines in cultured normal human prostate epithelial cells: predominance of vascular endothelial growth factor. Int J Cancer 1999;80:868-74.

9 Bocchietto E, Guglielmetti A, Silvagno F, et al. Proliferative and migratory responses of murine microvascular endothelial cells to granulocyte-colonystimulating factor. J Cell Physiol 1993;155:89-95.

10 Marino VJ, Sterin-Prync AE, Carbonetto $\mathrm{CH}$, et al. Conformational and sequential epitopes on the human granulocyte-colony stimulating factor molecule (hG-CSF) and their role in binding to human placenta receptors. Cyłokine 2001;16:41-50.

11 McCracken SA, Grant KE, MacKenzie IZ, et al. Gestational regulation of granulocyte-colony stimulating factor receptor expression in the human placenta. Biol Reprod 1999:60:790-6.

12 McCracken S, Layton JE, Shorter SC, et al. Expression of granulocyte-colony stimulating factor and its receptor is regulated during the development of the human placenta. J Endocrinol 1996; 149:249-58.

13 Uzumaki H, Okabe T, Sasaki N, et al. Identification and characterization of receptors for granulocyte colony-stimulating factor on human placenta and trophoblastic cells. Proc Natl Acad Sci USA 1989;86:9323-6.

14 Lindemann A, Riedel D, Oster W, et al. Recombinant human granulocytemacrophage colony-stimulating factor induces secretion of autoinhibitory monokines by U-937 cells. Eur J Immunol 1998;18:369-74.

15 de Koning JP, Schelen AM, Dong F, et al. Specific involvement of tyrosine 764 of human granulocyte colony-stimulating factor receptor in signal transduction 
mediated by $\mathrm{p} 145 /$ Shc/GRB2 or p90/GRB2 complexes. Blood 1996:87:132-40.

16 Dong F, van Buitenen C, Pouwels K, et al. Distinct cytoplasmic regions of the human granulocyte colony-stimulating factor involved in induction of proliferation and maturation. Mol Cell Biol 1993;13:7774-81.

17 Kobayashi K, Nishikawa M, Omay SB, et al. Forskolin potentiates G-CSFinduced proliferation of a murine myeloblastic leukemia cell line. Leuk Res 1994;18:111-17.

18 Thacker JD, Dedhar S, Hogge DE. The effect of GM-CSF and G-CSF on the growth of human osteosarcoma cells in vitro and in vivo. Int $J$ Cancer 1994; $56: 236-43$

19 Tachibana M, Miyakawa A, Tazaki $\mathrm{H}$, et al. Autocrine growth of transitional cell carcinoma of the bladder induced by granulocyte-colony stimulating factor. Cancer Res 1995:55:3438-43.

20 Dalton WS. The tumor microenvironment: focus on myeloma. Cancer Treat Rev 2003;29(suppl 1):11-19.

21 Eshel R, Neumark E, Sagi-Assif O, et al. Receptors involved in microenvironment-driven molecular evolution of cancer cells. Semin Cancer Biol 2002; 12:139-47.

22 Dumont N, Arteaga CL. The tumor microenvironment: a potential arbitrator of the tumor suppressive and promoting actions of TGFbeta. Differentiation 2002;70:574-82.

23 Arend WP. The mode of action of cytokine inhibitors. J Rheumatol Suppl 2002;65:16-21.

24 Avalos BR, Gasson JC, Hedvat C, et al. Human granulocyte colony-stimulating factor: biologic activities and receptor characterization on hematopoietic cells and small cell lung cancer cell lines. Blood 1990;75:851-7.

25 Kikuchi T, Nakahara S, Abe T. Granulocyte colony-stimulating factor (G-CSF production by astrocytoma cells and its effect on tumor growth. J Neurooncol 1996;27:31-8

26 Ninci EB, Brandstetter T, Meinhold-Heerlein I, et al. G-CSF receptor expression in ovarian cancer. Int J Gynecol Cancer 2000;10:19-26.

27 Tachibana M, Miyakawa A, Uchida A, et al. Granulocyte colony-stimulating factor receptor expression on human transitional cell carcinoma of the bladder. Br J Cancer 1997;75:1489-96.

28 Tsuzuki H, Fujieda S, Sunaga $H$, et al. Expression of granulocyte colonystimulating factor receptor correlates with prognosis in oral and mesopharyngeal carcinoma. Cancer Res 1998;58:794-800.
29 Corcione A, Pistoia V. B-cell-derived granulocyte-colony stimulating factor (GCSF). Methods 1997;11:143-7.

30 Mizuno K, Sone S, Orino E, et al. Autonomous expressions of cytokine genes by human lung cancer cells and their paracrine regulation. Jpn J Cancer Res 1994;85:179-86.

31 Quentmeier H, Zaborski M, Drexler HG. The human bladder carcinoma cell line 5637 constitutively secretes functional cytokines. Leuk Res 1997;21:343-50.

32 Kikuchi T, Nakahara S, Abe T. Granulocyte colony-stimulating factor (G-CSF) production by astrocytoma cells and its effect on tumor growth. J Neurooncol 1996;27:31-8.

33 Westphal G, Niederberger E, Blum C, et al. Erythropoietin and G-CSF receptors in human tumor cells: expression and aspects regarding functionality. Tumori 2002:88:150-9.

34 Hortner M, Nielsch U, Mayr LM, et al. Suppressor of cytokine signaling-3 is recruited to the activated granulocyte-colony stimulating factor receptor and modulates its signal transduction. J Immunol 2002;169:1219-27.

35 Dong F, Larner AC. Activation of Akt kinase by granulocyte colony-stimulating factor (G-CSF): evidence for the role of a tyrosine kinase activity distinct from the Janus kinases. Blood 2000;95:1656-62.

36 Morikawa K, Morikawa S, Nakamura M, et al. Characterization of granulocyte colony-stimulating factor receptor expressed on human lymphocytes. Br J Haematol 2002;1 18:296-304.

37 White SM, Alarcon MH, Tweardy DJ. Inhibition of granulocyte colonystimulating factor-mediated myeloid maturation by low level expression of the differentiation-defective class IV granulocyte colony-stimulating factor receptor isoform. Blood 2000;95:3335-40.

38 Bernard T, Gale RE, Linch DC. Analysis of granulocyte colony stimulating factor receptor isoforms, polymorphisms and mutations in normal haemopoietic cells and acute myeloid leukaemia blasts. Br J Haematol 1996;93:527-33.

39 Natori T, Sata M, Washida M, et al. G-CSF stimulates angiogenesis and promotes tumor growth: potential contribution of bone marrow-derived endothelial progenitor cells. Biochem Biophys Res Commun 2002;297: 1058-61.

40 Calatayud S, Warner TD, Breese EJ, et al. Modulation by colony stimulating factors of human epithelial colon cancer cell apoptosis. Cytokine 2002;20:163-7.

\section{Asian Pacific Digestive Week 2005}

The APDW will be held on 25-28 September 2005 at COEX, Seoul, Korea. Further information is available from Professor Jin-Ho Kim, Secretary General, University of Ulsan, 1510 Hyosung Olympic County II, 175-12, Chamsil-dong, Songpa-gu, Seoul, 138-220, Korea. Tel: +82 2412 0673; fax: +82 2412 0674; email: jhkm@amc.seoul.kr; web site: http://www:APDW2005.org 